\title{
Solusi Pendidikan dan Ketahanaan Pangan Masa Pandemi di Dukuh Tombol RT10/RW 04, Dalangan, Tulung, Klaten
}

\author{
Dhimas Adhinar Afriansyah ${ }^{\mathrm{a}, 1}$, Adhiputro Pangarso Wicaksono ${ }^{\mathrm{b}, 2, *}$, Burham Pranawa ${ }^{\mathrm{b}, 3}$ \\ ${ }^{a}$ Fakultas Ilmu Komputer, Universitas Boyolali, Boyolali, 57315, Indonesia \\ ${ }^{\mathrm{b}}$ Fakultas Hukum, Universitas Boyolali, Boyolali, 57315, Indonesia \\ ${ }^{1}$ afriansyah.nadia97@gmail.com ; ${ }^{2}$ adhiputro.pangarso@yahoo.com *; 3 burham_9@yahoo.com \\ * Koresponsendi penulis
}

ARTICLE INFO

Article history

Menerima 18 April 2021

Revisi 23 Juli 2021

Diterima 29 Juli 2021

Kata Kunci

Keamann Pangan

Belajar

Covid-19

\begin{abstract}
Food security is very much needed during the Covid-19 pandemic, where all activities are limited due to lockdown. The government advocates maintaining distance from each other and avoiding crowds. This socialization is to create a contribution to society in facing the Covid-19 pandemic to maintain food availability independently by inviting people to independently create living pharmacies and nutritional plants. So the hope is that residents do not need to shop for food needs outside the home because of the availability of various vegetables in the yard of the house. Student learning is also hampered. Because it is replaced by online learning, students have difficulty understanding the material, so parental guidance is needed.
\end{abstract}

This is an open access article under the CC-BY-SA 4.0 license.

\section{Pendahuluan}

Program Kuliah Kerja Nyata (KKN) merupakan program rutin sebagai bentuk Tri Dharma Perguruan Tinggi di Indonesia dengan menitikberatkan kepada kegiatan akademik yang bersifat intrakurikuler dan melibatkan masyarakat secara langsung [1]. Covid-19 dapat menularkan ke sesame manusia dan mempengaruhi aspek kehidupan masyarakat. Pandemi virus yang bernama "Severe Acute Respiratory Syndrome Coronavirus-2" (virus SARS-CoV-2) ini telah berdampak pada sektor pendidikan [2]. Sampai saat ini pesebaran COVID-19 semakin cepat.

Usaha pemerintah dalam menanggulangi penyebaran COVID-19 yang sangat cepat ini sudah mencakup banyak aspek kehidupan. Di bidang pendidikan, pemerintah menerapkan pelaksanaan program belajar di rumah [3]. Hal ini bisa melalui berbagai media berbasis internet maupun melalui media yang tidak berbasis internet [4]. Di bidang sosial pemerintah dengan gencar mencanangkan konsep mitigasi komunitas, berupa pengurangan frekuensi pertemuan besar, pembatasan jarak antar orang di fasilitas umum, hingga penerapan konsep aktivitas yang lebih baik dilaksanakan di rumah [5]. Bidang kesehatan, pemerintah telah dengan gencarnya mengedukasi kepada masyarakat terkait pentingnya hidup bersih dan sehat, perlunya mengenakan masker saat di luar rumah, pelaksanaan karantina mandiri untuk orang yang memiliki risiko tinggi, serta berbagai pedoman yang bertujuan untuk mencegah penularan COVID-19 [6]. Bidang 
agama, pemerintah melalui Majelis Ulama Indonesia (MUI) telah memberikan fatwa terkait dengan pelaksanaan ibadah di masa wabah pandemi COVID-19 [7]. Hingga pada tingkat desa, pemerintah telah mengeluarkan protokol terkait Relawan Desa Lawan COVID-19 [8].

Dukuh Tombol RT10/RW04, Dalangan, Tulung, Klaten berada sekitar 12-16 km ke arah utara kota Klaten di dukuh tombol mayoritas penduduknya adalah petani di dukuh tombol terdapat permasalahan tentang ketahanan pangan dan pendidikan sehimgga penulis mengambil tema ketahanan pangan dan pendidikan di masa pandemi pangan adalah "kondisi terpenuhinya Pangan bagi negara sampai dengan perseorangan, yang tercermin dari tersedianya pangan yang cukup, baik jumlah maupun mutunya, aman, beragam, bergizi, merata, dan terjangkau serta tidak bertentangan dengan agama, keyakinan, dan budaya masyarakat, untuk dapat hidup sehat, aktif, dan produktif secara berkelanjutan"[9].

Pendidikan di era pandemi Covid-19 saat ini menurut [1]tidak lepas dari peran mahasiswa sebagai agen problem solving bagi permasalahan yang ada di masyarakat, seperti melalui program Kuliah Kerja Nyata (KKN). Saat pandemi Covid-19, kegiatan KKN dilaksanakan secara mandiri dan tetap mengharuskan mahasiswa melakukan pemecahan masalah dan merumuskan masalah yang kompleks, seperti pendidikan. Salah satu bentuk peran aktif mahasiswa selama pandemi Covid-19 dapat melalui kegiatan KKN Tematik Covid-19 yang merupakan bentuk pengabdian kepada masyarakat dan Tri Dharma Perguruan Tinggi di bidang pendidikan [10]. Bidang pendidikan juga mengalami dampak yang sangat signifikan karena pandemi ini. Muhardi mengatakan bahwa kehidupan rakyatnya makmur dan sejahtera karena pembangunan bangsa melalui pendidikan [11]. Dapat dikatakan bahwa pendidikan adalah aspek penting untuk tercapainya kesejahteraan dan kemakmuran rakyat. karena pentingnya pendidikan di situasi pandemi covid-19, maka segenap pelaku pendidikan berpikir serius untuk tetap menstabilkan laju pendidikan di Indonesia. Anjuran pemerintah untuk melaksanakan pembelajaran di rumah di setiap satuan pendidikan mulai dari PAUD sampai Perguruan Tinggi. Maka solusinya adalah dengan tetap menjalankan proses pembelajaran dengan menggunakan sistem belajar daring atau online.

Mahasiswa Universitas Boyolali (UBY) diharapkan dapat memberikan kontribusi nyata untuk membantu masyarakat melalui program KKN. Adanya KKN-UBY ini diharapkan dapat mengedukasi masyarakat akan Covid-19 dan pencegahan dengan menerapkan protokol kesehatan serta membantu pendidikan anak-anak dengan adanya pembelajaran online karena sebagian anak memerlukan pendampingan belajar dan mengenalkan kepada masyarakat tentang ketahanan pangan . Tujuan kegiatan untuk mengedukasi masyarakat mengenai protokol kesehatan agar masyarakat semakin sadar dan mengerti bahaya Covid19.

\section{Metode}

Metode yang digunakan dalam program KKN yang akan dilakukan terdiri dari empat tahapan yaitu :

Tahap pertama yang dilakukan yaitu pendambingan belajar anak-anak pelaksanaan dilaksanakan secara langsung (tatap muka) di ikuti kurang lebih 10 peserta. Bimbingan yang diajarkan adalah menggambar dan membaca, menulis, belajar menghitung yang bertempat di rumah ibu Khusnul Dukuh Tombol RT10/RW04, Dalangan, Tulung, Klaten.

Tahap kedua yang dilakukan yaitu sosialisai ketahanaan pangan di masa pandemi pelaksanaan dilaksanakan di Dukuh Tombol RT10/RW04, Dalangan, Tulung, Klaten secara langsung (tatap muka). Sosialisasi Ketahanan pangan keluarga di masa pandemi dilaksanakan dengan cara door to door kerumah warga dan memberikan tanaman cabe dan tomat.

Tahap ketiga yang dilakukan yaitu sosialisai dan penempelan stiker 3M pelaksanaan dilaksanakan di Dukuh Tombol RT10/RW04, Dalangan, Tulung, Klaten secara langsung/tatap 
muka. Penempelan stiker 3M dengan cara datang kerumah dan memberikan edukasi ke warga agar mematuhi anjuran pemerintah untuk tidak berkerumun, jaga jarak dan pakai masker.

Tahap keempat yang dilakukan yaitu sosialisasi dan memberiakan tempat cuci tangan pelaksanaan dilaksanakan di Dukuh Tombol RT10/RW04, Dalangan, Tulung, Klaten secara langsung yang di lakukan. Memberikan cuci tangan dan tempat sampah di tempat strategis agar warga rajin mencuci tangan dan tidak membuang sampah sembarangan. Kegiatan tersebut di hadiri Ketua RT dan Wakil RT.

\section{Hasil dan Pembahasan}

a. Sosialisai dan Pembuatan stiker 3M

Untuk menghimbau masyarakan akan pentingnya menerapkan 3M (Memakai Masker, Mencuci Tangan dan Menjaga Jarak). Karena penerapan 3M guna mencegah penularan covid-19. Pembuatan stiker ini ssebagai salah satu sarana pendukung dalam penyampaian materi yang dilakukan secara mendatangi rumah warga.



Fig. 1. pembuatan stiker $3 \mathrm{M}$

b. Sosialisasi dan Pembuatan Tempat Cuci Tangan

Upaya ini dilakukan untuk membantu melakukan pencegahan penyebaran virus covid-19. Mencuci tangan dengan tepat mampu mencegah terjangkit penyakit pencernaan dan pernafasan.

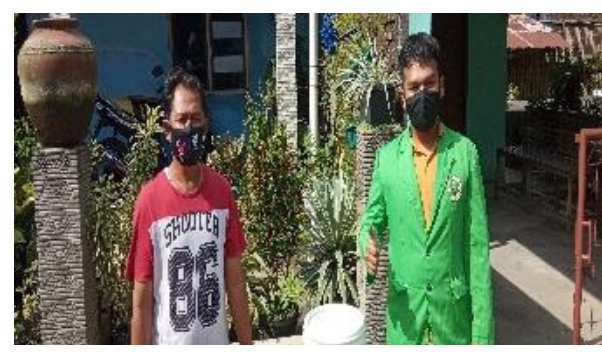

Fig. 2. Pembuatan Tempat Cuci Tangan

c. Sosialisasi Ketahanan Pangan

Sosialisasi ini berguna untuk mewujudkan kontribusi terhadap masyarakat dalam mengahadapi pandemi covid-19 untuk mempertahankan ketersediaan pangan secara mandiri dengan mengajak masyarakat untuk menanam tanaman gizi secara mandiri. Jadi harapan warga tidak perlu belanja kebutuhan pangan diluar rumah karena tersediannya aneka sayur dipekarangan rumah. 


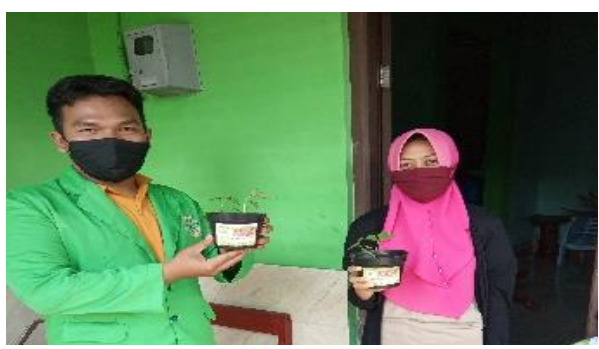

Fig. 3. Sosialisasi Ketahanan Pangan

d. Pendampingan anak dalam belajar

Materi pendampingan belajar meliputibelajar membaca menulis dan menghitung. Dalam pembelajaran dilakukan secara tatap muka. Kegiatan ini juga memotivasi semangat belajar siswa dan menunjukan prestasinya.

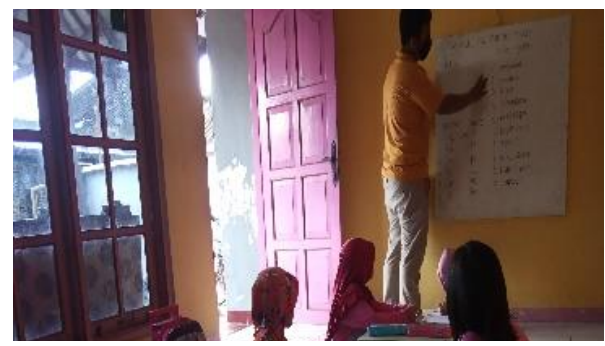

Fig. 4. Pendampingan Belajar

\section{Kesimpulan}

Pelaksanaan program KKN di Dukuh Tombol, Desa Dalangan, Kecamatan Tulung, Kabupaten Klaten. Selama 1 bulan lebih yaitu pada tanggal 21 Februari - 31 Maret 2021 merupakan serangkaian kegiatan yang saling berhubungan antara pelaksanaan dan pelaporan hasil kegiatan. Oleh karena itu, keduanya harus sejalan. Secara garis besar berbagai program yang direncanakan telah terlaksana dengan baik. Beberapa program kerja yang telah terpenuhi antara lain sebagai berikut: Sosialisasi dan Pembuatan tempat cuci tangan umum, Sosialisasi dan Pembuatan Stiker 3M, Sosialisasi ketahanaan pangan, Pendampingan Belajar anak-anak.

Dari kegiatan-kegiatan yang telah terlaksana diatas dapat disimpulkan bahwa program kerja selama KKN. Secara garis besar berbagai program yang telah direncanakan, terlaksana dengan baik terhadap program-program yang dilaksanakan. Dari sisi yang lain, sambutan dan partisipasi dari masyarakat sangat baik terhadap program-program yang telah dilaksanakan. Hal ini dapat dilihat dari keikutsertaan warga, baik dari kalangan pengurus, orang tua, maupun anak-anak yang sangat antusias mengikuti pelaksanaakan program KKN.

\section{Ucapan Terima Kasih}

Penulis mengucapkan terima kasih kepada seluruh pihak yang telah membantu dalam kegiatan KKN ini sehingga setiap program kegiatan bisa berjalan sesuai rencana dan terima kasih kepada warga masyarakat dukuh tombol yang ikut serta dalam kegiatan KKN ini .

\section{Daftar Pustaka}

[1] R. R. Al Hakim, "Pencegahan Penularan Covid-19 Berbasis Aplikasi Android Sebagai Implementasi Kegiatan KKN Tematik Covid-19 di Sokanegara Purwokerto Banyumas," Community Engagem. Emerg. J., vol. 2(1), pp. 7-13, 2020, doi: https://doi.org/10.37385/ceej.v2i1.125.

[2] Al Hakim, R. R., E. Rusdi, and M. A. Setiawan, "Android Based Expert System Application for Diagnose COVID-19 Disease : Cases Study of Banyumas Regency," J. Intell. Comput. 
Heal. Informatics, vol. 1(2), pp. 1-13, 2020, doi:

https://doi.org/https://doi.org/10.26714/jichi.v1i2.5958.

[3] Kemendikbud, "Perluas Akses Belajar di Masa Covid-19, Mendikbud Luncurkan Program Belajar dari Rumah' Kementerian Pendidikan dan Kebudayaan,” 2020.

https://www.kemdikbud.go.id/main/blog/2020/04/perluas-akses-belajar-di-masa-covid19mendikbud-luncurkan-program-belajar-dari-rumah (accessed Jul. 23, 2021).

[4] Darmalaksana, W., R. Hambali, A. Masrur, and M. Muhlas, "Analisis Pembelajaran Online Masa WFH Pandemic Covid-19 sebagai Tantangan Pemimpin Digital Abad 21," Karya Tulis Ilm. Masa Work From Home Covid-19 UIN Sunan Gunung Djati Bandung, pp. 1-12, 2020.

[5] N. R. Yunus and A. Rezki, "Kebijakan Pemberlakuan Lock Down Sebagai Antisipasi Penyebaran Corona Virus Covid-19," J. Sos. dan Budaya Syar-i, vol. 7(3), 2020.

[6] D. Telaumbanua, "Urgensi Pembentukan Aturan Terkait Pencegahan Covid-19 Di Indonesia," J. Pendidikan, Sos. dan Agama, vol. 2(01), pp. 59-70, 2020.

[7] MUI, Fatwa Majelis Ulama Indonesia Nomor: 14 Tahun 2020 Tentang Penyelenggaran Ibadah Dalam Situasi Terjadi Wabah Covid-19. Jakarta: Komisi Fatwa Majelis Ulama Indonesia, 2020.

[8] Kemendesa, Protokol Relawan Desa Lawan COVID-19. Jakarta: Kementerian Desa, Pembangunan Daerah Tertinggal, dan Transmigrasi, 2020.

[9] Bappenas, Rencana Aksi Nasional Pangan dan Gizi 2011. Jakarta: Badan Perencanaan, 2011.

[10] S. D. Prasetyo and Y. Suherlan, "KKN UNS Era Covid-19 di Rt 03 Rw 07 Desa Panjer Kecamatan Kebumen," J. Penelit. Dan Pengabdi. Masy., vol. 1(1), pp. 1-11, 2020.

[11] Muhardi, "Kontribusi Pendidikan Dalam Meningkatkan Kualitas Bangsa Indonesia," Mimbar, vol. xx(4), pp. 478-492, 2004, doi: doi:doi.org/10.3171/jns.2000.93. 